\title{
The Role Of Business Incubators In The Economic Development Of Saudi Arabia
}

\author{
Mohamed Imam Salem, King Saud University, Kingdom of Saudi Arabia
}

\begin{abstract}
Business incubators are perceived to be a mainstay of economic development programs. They create value by combining the entrepreneurial drive of a startup with resources generally available to new ventures. Among the primary objectives of business incubators are creating employment opportunities in the local economy and commercializing technologies. Saudi government has put high-growth, innovative businesses at the heart of its economic agenda.

The aim of this paper is to enhance understanding of how business incubators function and their impact on national development and growth of a developing nation. First, the paper reviews the literature on the relationship between business incubators and economic development; then the paper provides an analysis of the characteristics and objectives of business incubators in Saudi Arabia. The paper also examines the significant contribution of business incubators in promoting economic growth and development of Saudi Arabia. The paper points out the importance of introducing business incubator strategies and programs and the role of such important moves in ensuring sustainable value creation and building of wealth.
\end{abstract}

Keywords: Entrepreneurship; Business Incubators; Economic Development; Economic Growth; Saudi Arabia

\section{INTRODUCTION}

(8) everal changes in the global economy resulting from globalization, advancement in technology, accelerated innovations, and trends in demographics calls for the need to improve levels of entrepreneurship which also plays a crucial role in their improvement of growth and development. Entrepreneurship is an important factor in facilitating poverty reduction, creation of employment opportunities, and structural changes within its context. In essence, entrepreneurship is an important tool for improving living standards and the general well-being of the society. Additionally, the creation of new ventures is an important strategy applied by governments in the quest for attaining sustainable national economic growth and development. It is also important for the development and achievement of competitive economies in the national and international levels.

The year 2010, for instance, saw the launch of a new decade of entrepreneurship efforts and innovations in the Kingdom of Saudi Arabia (KSA). The need to launch such important economic strategies is to place the Kingdom at the membership of top economic competitive nations in the world. This calls for the need for a vibrant economy in the Kingdom driven by entrepreneurship and creativity. In this context, entrepreneurship is very instrumental to the economic growth and development of developing nations. Economic research indicates that small and medium enterprises in developing countries make up to approximately 92 percent of businesses, while at the same time employing over 80 percent of the total workforce in those countries. It is for this reason that there are significant indicators and the need for developing countries to commit themselves toward the nurturing of the next generation of entrepreneurs, business leaders, and innovators to achieve sustainable growth and development (Michelle, 2003).

The initiation of various business support programs in the KSA, for instance, aims at improving the performance of small and medium enterprises, nurturing talent and entrepreneurial skills, and provision of entrepreneurial training programs. Business incubator initiatives, like those carried out by Saudi Business Incubator Network initiative, are specifically designed to promote steadfast entrepreneurship and innovation to promote 
development of new businesses that eventually result in increased job opportunities and enhanced economic growth. According to Alfantookh \& Bakry (2013), promoting innovation and technology transfer through learning institutions, as carried out by the Saudi Arabia university incubators also enhances business growth. Additionally, entrepreneurial training and programs, as provided by various business support programs, are necessary for new business startups. Saudi Arabia's government initiatives toward young business enterprises that record positive performance also serve as a motivating factor for such enterprises to ensure improved performance and sustainable growth.

The impact of the cultivating entrepreneurial ecosystem in Saudi Arabia is also taking its impact to the neighboring regions. It is evident that major changes are afoot in the Middle East and North Africa (MENA) region where a new breed of young and highly innovative entrepreneurs are gradually reshaping the economic landscape of the region, while at the same time overcoming the challenges of longstanding assumptions that kept jeopardizing value creation and risk aversion in the developing nations. This paper therefore uses the context of the KSA to analyze business incubators in relation to economic development and growth in the region.

The paper consists of five sections. The first section reviews the literature on the relationship between entrepreneurship, business incubators, and economic development. The second section provides an overview of the role that business incubators play in the economic development and growth of a country. The third section offers an analysis of the characteristics and objectives of business incubators in Saudi Arabia and it reveals the initiatives of Saudi government to promote and develop business incubators. The fourth section sheds light on the pivotal role that business incubators play in the economic growth and development of Saudi Arabia and, finally, the last section outlines the conclusion and policy implications.

\section{BUSINESS INCUBATORS AND ECONOMIC DEVELOPMENT: AN OVERVIEW}

Over the past few decades, business incubation has been attracting many research studies in developed and developing countries. This is achievable through the analysis of business policies that support economic growth and development. The term 'business incubation' implies a business development strategy utilized by policy makers and nations to ensure sustainable economic growth and development through the creation of entrepreneurial ventures that are effective in the contribution of economic growth and a health status of the economy. Successful incubation, as applied by various countries, involves a supportive environment that facilitates the creation of new ventures and fulfillment of potential growth and giving such ventures the access to a wide range of business development resources. It also entails providing new ventures with tailored services. Therefore, business incubation is significant in seeding and developing new business ventures alongside technology transfer to facilitate potential growth in most economic sectors within a country (Pappas, 2003).

In various developed countries across the globe, the use of incubation emerged as early as 1980's, while operating alongside other generic business development programs, and later on evolved into narrow and very deep business services for supporting small selected groups of companies. Subsequently, developing countries began to adopt the concept of business incubation. The use of traditional business incubation methods, and their importance in enhancing growth and development, was the motivation factor behind the adoption of business incubation programs among various developing countries. As argued by various economists, business incubation is a very vital tool in nurturing entrepreneurship and the development of small and medium enterprises to create more job opportunities, consequently leading to improved standards of living (Volkmann, 2004).

According to Pappas (2003), the incubation program is one of the most dynamic programs aimed at developing and supporting new commercial businesses. Incubators have the ability of nurturing young firms by helping them to survive during their startup stages and maintain a sustainable growth thereafter. Most importantly, helping new firms survive during their startup stages is the most crucial function of business incubators owing to the fact that, at this particular period, most new firms are vulnerable to failure and collapse. Additionally, business incubators are important in providing hands-on management practices, provision of the necessary resources, and orchestrated exposure to business strategies on critical thinking, and provision of the most important technical support for business success. Furthermore, business incubators are useful in providing new firms with the facilities to share office services, easy access to business equipment, and expandable space. 
According to a survey conducted by Hackett and Dilts (2004) that concentrated in Asia and North America regions, business incubator programs imply a shared office space facility that assists entrepreneurs with the strategies or tenant companies to facilitate business monitoring and assistance. This is important since the business incubator helps in controlling and linking necessary resources that facilitate the development of client's new ventures through the ability to contain the cost of potential threats and failures in the business.

However, the establishment of such business incubators could depend on the different set of objectives to reflect specific operating environments and the stakeholders' needs. It is also important to note that the design of each incubator is in a certain manner that seeks to drive one or more objectives, like commercial viable venture, facilitating technology transfer, enhancing innovation, and encouraging economic development. According to Lalkaka (2002), other objectives may include the creation of new employment opportunities, accelerating business growth, empowerment, and developing role models to create a good entrepreneurial culture.

Governments initiate business incubators to promote economic developments and growth of the entire nation or to enhance growth in specific communities or regions of the country. In particular, this ideology is important in regions like the United States where there is widespread application and utilization of business incubators that rely mostly on technology to support local and state economic growth. Wagner (2006) argues that the growth of business incubators globally is justifiable through various established theoretical dimensions based on previous and existing empirical evidence that support the role of innovation and technology in promoting economic growth. Such business incubation programs are also important in speeding up the rate of growth and development among the developing nations like the Kingdom of Saudi Arabia.

However, business incubators do not play a part in the transformation of national, community, or regional economy. Nonetheless, literature proves that the integration of business incubators in economic policy reform, in its broader perspective, is of great importance. It is also important to integrate business incubator programs in other reforms, like those of infrastructure investment and financing, to ensure speedy and sustainable economic growth and development. In such situations, having a clear understanding of the objectives of and missions of business incubator programs is of much importance in achieving the expected return on the resources invested in the general program.

According to Lalkaka (2006), understanding the requirements and objectives of business incubator programs brings about the accurate and necessary measures of providing entrepreneurs with the appropriate expertise, tools, networking, and capital for business startup. In this regard, the business incubator is not only a business tool but also one that goes beyond its scope to provide effective training for entrepreneurs to ensure that ventures and technology transfers are successful in the business environment.

Furthermore, business incubation programs are proven effective in ensuring diversification of economies, technology commercialization, creation of employment opportunities, and wealth creation (Peters, Rice, \& Sundararajan, 2004). The National Business Incubation Association (NBIA) also argues that business incubator programs are useful in ensuring that entrepreneurs have the ability to translate their ideas into sustainable and highly successful and functioning business investments by guiding them through the startup period and throughout the growing and development stages. As mentioned earlier, the most crucial importance of business incubator programs is provision of support to entrepreneurs during the vulnerable startup period. This ensures that there is a reduction in failure rate of new businesses during the initial stages of entrepreneurial process (Peters et al., 2004). In this regard, business incubator programs provide entrepreneurs with an upper hand in ensuring the success of new business ventures and the assurance of value creation (Michelle, 2003).

The National Business Incubator Association, by virtue of its position as one of the world's leading organizations in advocating and promoting business incubation programs and entrepreneurship, plays a very pivotal role in ensuring the initiation and implementation of economic development and growth programs. The NBIA provides dozens of professional entrepreneurs with the necessary information, skills, education advocacy, and resource mobilization strategies to bring about efficient and effective startup of companies (NBIA, 2006). The association appreciates that business incubation is one of the most effective and innovative tools that facilitates economic development and growth in various countries across the globe. 


\section{BUSINESS INCUBATORS IN SAUDI ARABIA: CHARACTERISTICS AND OBJECTIVES}

Business incubators differ from other types of programs aimed at enhancing business support. Proper formulation of business incubators is effective in facilitating entrepreneur support through the provision of capital, training, and technology transfer. This facilitates startup of new businesses is also important for economic development through the creation of employment opportunities. These programs also focus on supporting entrepreneurs from the region through feasible business ideas and concepts to ensure launching of new products.

The Kingdom of Saudi Arabia applies the use of various types of business incubators in promoting business activities within the region, especially in the establishment of new businesses and support for small and medium enterprises with low financial capacity. The system of business incubator classification adopted by Albert and Gaynor (2001) is very important in analyzing the types of business incubators used in the KSA. The choice of the types of incubators used for promoting businesses in the KSA is important in determining the success of the business incubator programs and should be in relationship with the specific business objectives and goals. Therefore, the choice of the type of business incubator depends on the business objectives of the program.

The most important type of business incubators in the Kingdom of Saudi Arabia is the university-based business incubators. As mentioned earlier, business incubators play a key role in supporting and promoting nascent entrepreneurs, particularly during the startup periods of their firm's life cycle. University type of business incubators is not exceptional in pursuing such goals and objectives. University business incubators provide clients with a range of services that include shared offices, access to sophisticated business equipment and software services, and network pools that promote startup companies. These kinds of business support provide entrepreneurs and their startup enterprises a relatively secure environment and a head start over others (Peters et al., 2004). University business incubators, as used in the KSA, provide a unique opportunity to young and highly promising entrepreneurs to benefit from the knowledge acquired in the university and the wide range of resources provided by the university, particularly in starting new business ventures that require a higher level of knowledge, research, and technology.

Most of the types of business incubators used by the KSA are characterized by involvement of private sectors and monitoring of performance of entrepreneurs and new business enterprises. The Saudi Business Incubator Network (SBIN), for instance, strives to monitor the performance of young entrepreneurs and the performance of new business enterprises from startup to a point where such businesses can run without the support of incubator services. In their bid to ensure support for small and medium enterprises, the business incubators are also characteristic of providing entrepreneurs with unique resources like licenses to startup businesses, knowledge, training, and technology that is necessary for new businesses. This ensures a reduced number of business failures after startup.

In addition, it is important to note that young student entrepreneurs in Saudi universities benefit from university business incubators and research in industries to enable them startup of their businesses and technology transfer. According to Grimaldi and Grandi (2005), university incubators also focus on generation and transfer of technological knowledge from classroom setup to industries and companies. Grimaldi and Grandi (2005) further argue that university business incubators are characteristic of being major outlets to facilitate commercialization of university research and knowledge to facilitate economic growth and development. In addition, university business incubators have resources that could otherwise be expensive for entrepreneurs to access. For instance, universities are rich of technology, new knowledge-based business startups, and good absorptive capacity.

Another important characteristic of the university business incubators used by the KSA is the provision of two services to clients. Such services include those related to incubation and those related to university. Universities add value to small and medium enterprises by providing shared office services, receptionist services, security, fax, and photocopiers. Furthermore, clients also enjoy rent breaks and proper business advice services provided by the universities. Among the university-related services provided by the university type of incubators are student employees, information databases, workshops, technology transfer, faculty consultants, and sophisticated equipment. All these types of services are important in adding value to new businesses and partnerships (Peters et al., 2004). 
Just like in any other country, the objectives of business incubator programs in the KSA are those of contribution to economic development and growth within the region. The Saudi government and policymakers appreciate the need to attain economic transformation through integration of business incubator programs in the mainstream economic policy reform. In their quest for economic transformation that translates to sustainable growth and development, the Saudi authorities aim at using business incubators to attain new business formation and business expansion.

Business stabilization is also another very important objective of Saudi business incubator policies. Since the launch of Saudi Fast Growth 100 initiative in 2010, the Kingdom has been on an aggressive research and investigation on the ways that business incubators can be useful in stabilizing existing small and medium size enterprises that have a poor economic base. The purpose of such business incubator programs is to provide support and guidance services aimed at stabilizing businesses and cutting down the chances of failure by greater margins.

Saudi Arabia's policymakers also have the objective of intending to expand businesses through initiation of business incubator programs in the region. Deploying business incubators in the bid to expand the existing small and medium size business enterprises is an important move in ensuring sustainable national growth and development. In their quest to attain these objectives, Saudi authorities seek to provide business incubator services aimed at helping entrepreneurs to improve business operational efficiency, securing capital, hiring and managing labor, expanding production levels, and identifying new market opportunities.

\section{BUSINESS INCUBATORS AND ECONOMIC DEVELOPMENT IN SAUDI ARABIA}

The contribution of business incubators in economic development and growth in most parts of the world is evident by its application in developed countries. Likewise, the Kingdom of Saudi Arabia is not an exception in realizing the economic benefits of initiating business incubator programs to facilitate its intention of attaining sustainable economic growth and development.

Over the last few years, Saudi Arabia's government has been on an aggressive direction of pursuing its movement toward the knowledge-based economy in the world. The government's policies to assign various private and government institutions to guide the framework of such economic perspective is an important move in attaining the standards and benefits of economic development and growth that come with business incubation. Institutions like the Prince Sultan Fund to Support Women's Small Enterprises, Saudi Arabian General Investment Authority (SAGIA), the Prince Salman Young Entrepreneurship Awards, the National Entrepreneurship Centre, the Prince Salman Entrepreneurship Institute, and the King Abdullah University of Science and Technology (KAUST) are among the various institutions mandated by the government to facilitate Saudi Arabia's economic transition progress. The government also made King Saud University the home of the government's policy dubbed Riyadh Technology Incubation Centre to oversee the progress of the business incubation programs in the Middle East region (Alshumaimri, Aldridge, \& Audretsch, 2010).

On the other hand, the government-instituted SAGIA has pledged to make the Kingdom of Saudi Arabia one of the most competitive business hubs across the globe through ambitious nurturing of emerging entrepreneurs and businesses. The leadership of King Abdullah also appreciates and recognizes the important role of a new generation of entrepreneurs in the development of Saudi economy and the attainment of sustainable competitiveness in the Kingdom (National U.S.-Arab Chamber of Commerce, 2010). Additionally, among the government's policies in ensuring successful business incubator programs is Prince Sultan Bin Abdulaziz's Fund initiative aimed at improving and nurturing women entrepreneurs in the region. The initiative kicked off in 2007 with the view of supporting women entrepreneurs in starting up new enterprises.

According to Al-Kurdi (2002), business incubator programs in the KSA have been useful in ensuring strengthened technological standards of small and medium enterprises in the region. The author argues that the use of business incubators in developing countries ensures the enhancement of improved trends in business liberalization. This implies that the promotion of business incubators in the KSA and the initiation of technology parks are important in fostering the country's economic development and growth (Al-Kurdi, 2002). 
Furthermore, Radwan and Al-Kibbi (2005) provide a range of benefits that the KSA reaps from initiating business incubator programs. The authors argue that Saudi Arabia's small and medium enterprises keep gaining a lot of success through inter-firm linkages that serve as factors for enhancing individual competence and capabilities through accelerated collective efforts rooted in the important areas of manufacturing value chain. The small businesses also benefit from a wide range of bulk sourcing of raw materials and the facilitated sharing of key facilities that include testing calibration and warehousing (Radwan \& Al-Kibbi, 2005). This also implies that Saudi entrepreneurs benefit from meeting market standards, highly enhanced technology capabilities, and collective entrepreneurial training. The use of technology in various sectors of the economy also helps entrepreneurs in accessing advanced services that foster productivity within their industries.

Moreover, the university business incubators also play a very crucial role in nurturing entrepreneurial skills among students. The main objective of the university incubators is to provide valuable services to young entrepreneurs by leveraging knowledge and talent within the university and ensuring sustainable creation of value. Universities also ensure provision of new opportunities to ensure local customization of products, creation of new employment opportunities, and to link talented students to various industries for economic development. According to Grimaldi and Grandi (2005), the main objectives of university incubators is to lend resources and talent to boost efforts for economic development.

Finally, the Kingdom of Saudi Arabia benefits from business incubator programs through the support of commercial and industrial service environment, improved job creation, expanded business base for entrepreneurial participation, enhanced market and financial intelligence, adoption of new technological concepts in tangible business ideas, and reduction in levels of risks of new business failures (Al-Dosary, Rahman, \& Aina, 2006).

\section{CONCLUSION AND POLICY IMPLICATIONS}

This paper analyzes the role of business incubators in relation to Saudi economic development and growth. Changes in the global economy, coupled with accelerated technological advancements, call for the need for accelerated business policies that help in the improvement of country, community, and region's economic development through integration of business incubator programs in economic policies to bring about transformation in business and economic sectors. It is for this reason that most countries across the globe, and especially countries in developing regions, are embarking on aggressive strategies to initiate business incubator strategies to facilitate their economic growth and to meet their needs for sustainable economic growth.

This paper defines business incubator programs as initiatives aimed at supporting new entrepreneurs and promoting emerging small and medium enterprises to ensure the creation of employment opportunities that, in turn, result in the build-up of wealth and value creation. At the core of business incubator initiatives lay the issue of commercialization and transfer of technology. There is also a need to provide entrepreneurs with the necessary requirements for starting up a successful business, like capital, training, and empowerment of the minority groups. For instance, the study points out Saudi Arabia's business incubator policies that promote women entrepreneurs and nurture leadership skills in young Saudi girls. Finally, the paper also analyzes various types of business incubator programs. This paper also highlights the objectives of the business incubator policies initiated by the Saudi government aimed at establishing new businesses, creation of job opportunities, offering training to entrepreneurs, stabilizing new businesses that have a poor financial base, and expanding existing businesses.

\section{AUTHOR INFORMATION}

Mohamed Imam Salem is a faculty member and senior researcher at Prince Salman Entrepreneurship Institute, King Saud University, Kingdom of Saudi Arabia. E-mail: miisalem@ hotmail.com

\section{REFERENCES}

1. Albert, P., \& Gaynor, L. (2001). Incubators-growing up, moving out: A review of the literature in European foundation for management development. ARPENT: Annual Review of Progress in Entrepreneurship. Brussels: EFMD. 
2. Al-Dosary, F., Rahman, S., \& Aina, Y. (2006). A communicative planning approach to combat graduate unemployment in Saudi Arabia. Human Resource Development International, 9(3), 397-414.

3. Alfantookh, A., \& Bakry, S. H. (2013). Creativity and innovation in higher education research: Problems and solutions. International Journal of Knowledge Society Research (IJKSR), 4(1), 90-107.

4. Al-Kurdi, U. (2002). New approaches to small and medium enterprises development. Background paper presented for the Small and Medium Enterprises Session at the Future Vision of the Saudi Economy Symposium held by Kingdom of Saudi Arabia, Ministry of Planning, Riyadh.

5. Alshumaimri, A., Aldridge, T., \& Audretsch, D. (2010). The university technology transfer revolution in Saudi Arabia. Journal of Technology Transfer, 35(6), 585-596.

6. Erlewine, M., \& Gerl, E. (2004). A comprehensive guide to business incubation. Athens, Ohio: National Business Incubation Association.

7. Grimaldi, R., \& Grandi, A. (2005). Business incubators and new venture creation: An assessment of incubating models. Technovation, 25(2), 111-121.

8. Hacklett, S., \& Dilts, M. (2004). A syatematic review of business incubation research. Journal of Technology Transfer, 29(1), 55-82.

9. Lalkaka, R. (2002). Technology business incubators to help build an innovation-based economy. Journal of Change Management, 3(2), 167-176.

10. Lalkaka, R. (2006). Technology business incubation: A toolkit on innovation in engineering, science and technology. Paris: UNESCO Pub.

11. Lourenco, M. (2004). Understanding communication network development and business incubation. Kentucky: University of Louisville.

12. Michelle, S. (2003). Business incubation in inner-city emerging markets as economic development tool. Texas: University of Texas.

13. NBIA. (2006). State of the business incubation industry. Retrieved from: www.nbia.org

14. National U.S.-Arab Chamber of Commerce. (2010). Incubating the future: Entrepreneurship in Saudi Arabia. National U.S.-Arab Chamber of Commerce, 18(1), 2010. Retrieved from http://www.saudiembassy.net/files/PDF/Publications/Magazine/US-Arab_Tradeline_Spring_2010.pdf

15. Pappas, P. (2003). The university's role in economic development: From research to outreach. San Francisco: Jossey-Bass.

16. Peters, L., Rice, M., \& Sundararajan, M. (2004). The role of incubators in the entrepreneurial process. Journal of Technology Transfer, 29, 83-91.

17. Radwan, I., \& Al-Kibbi, J. (2002). Small and medium enterprise development: A version for action in Saudi Arabia. Background Paper Presented for the Small and Medium Enterprises Session at the Future at the Future Vision of the Saudi Economy Symposium held by Kingdom of Saudi Arabia Ministry of Planning. Riyadh.

18. Volkmann, C. (2004). Entrepreneurship studies - An ascending academic discipline in the twenty-first century. Higher Education in Europe, 29(2), 177-185.

19. Wagner, K. (2006). Business development incubator programs: An assessment in Missouri. San Francisco: Capella University Press. 
NOTES 